\title{
Rowe's Arguments from Evil
}

In a series of papers over the past thirty-five years, William Rowe-(1979), (1986), (1991), (1996), (2001a), (2001c) — has claimed that the kinds and amounts of suffering to be found in our universe are evidence that our universe was not created by an omnipotent, omniscient and perfectly good god. Moreover, and at the same time, Rowe has advanced a series of arguments against the existence of God that turn on considerations about the kinds and amounts of suffering to be found in our universe.

In saying that the kinds and amounts of suffering to be found in our universe are evidence that our universe was not created by an omnipotent, omniscient and perfectly good god, Rowe does not mean to be claiming that the kinds and amounts of suffering to be found in our universe are immediately decisive evidence that our universe was not created by an omnipotent, omniscient and perfectly good god. After all, there is - or, at any rate, may beother evidence that bears on the hypothesis that our universe was created by an omnipotent, omniscient and perfectly good god, and we cannot simply assume that whatever other evidence there is does not outweigh the negative evidence of the kinds and amounts of suffering to be found in our universe.

Once we recognise that the kinds and amounts of suffering to be found in our universe are not immediately decisive evidence that our universe was not created by an omnipotent, omniscient and perfectly good god, a range of questions opens up. Should we suppose that the kinds and amounts of suffering to be found in our universe are decisive evidence that our universe was not created by an omnipotent, omniscient and perfectly good god? Should we suppose that the kinds and amounts of suffering to be found in our universe are strong evidence that our universe was not created by an omnipotent, omniscient and perfectly good god? Should we suppose that the kinds and amounts of suffering to be found in our universe are so much as evidence that our universe was not created by an omnipotent, omniscient and perfectly good god?

I think - though I admit to some uncertainty on these matters - that Rowe's considered opinion is something like the following. On the one hand, those who believe that our universe was not created by an omnipotent, omniscient and perfectly good god may be perfectly within their doxastic rights in supposing that the kinds and amounts of suffering to be found in our universe are decisive evidence that our universe was not created by an omnipotent, omniscient and perfectly good god - that is, they may perfectly reasonably maintain that the kinds and amounts of suffering to be found in our universe outweigh all of the evidence (if, indeed, there is any) that favours the hypothesis that our universe was created by an omnipotent, omniscient and perfectly good god. On the other hand, those who believe that our universe was created by an omnipotent, omniscient and perfectly good god may be perfectly within their doxastic rights in supposing that the kinds and amounts of suffering to be found in our universe are outweighed by evidence that favours the hypothesis that our universe was created by an omnipotent, omniscient and perfectly good god. However, all should agree that the kinds and amounts of suffering to be found in our universe are evidence 
that our universe was not created by an omnipotent, omniscient and perfectly good god - and perhaps all should agree that the kinds and amounts of suffering to be found in our universe are strong evidence that our universe was not created by an omnipotent, omniscient and perfectly good god. While it is a matter for judgment - something about which sensitive, thoughtful, intelligent, well-informed people can reasonably agree to disagree-whether the kinds and amounts of suffering to be found in our universe outweigh the evidence that our universe was created by an omnipotent, omniscient and perfectly good god, it is not a matter for judgment — not something about which sensitive, thoughtful, intelligent, well-informed people can reasonably agree to disagree - whether the kinds and amounts of suffering to be found in our universe are evidence that our universe was not created by an omnipotent, omniscient and perfectly good god; and it is perhaps also not a matter for judgment - not something about which sensitive, thoughtful, intelligent, well-informed people can reasonably agree to disagree - whether the kinds and amounts of suffering to be found in our universe are strong evidence that our universe was not created by an omnipotent, omniscient and perfectly good god.

\section{Two Cases}

There are two cases of intense suffering that have loomed particularly large in the recent literature. So we begin with a brief exposition of these two cases.

Rowe (1979: 337) focuses on a case of animal suffering (E1):

Suppose in some distant forest lightning strikes a dead tree, resulting in a forest fire. In the fire a fawn is trapped, horribly burned, and lies in terrible agony for several days before death relieves its suffering.

E1 is a clear case of natural evil-i.e., a case in which no human agents bear any responsibility for the resulting suffering. Since there have been mammals on earth for at least 200, 000, 000 years - not to mention the further fact that there have been animals on the earth for at least 600,000, 000 years - we can be sure that there has been a very large amount of suffering of this kind.

Rowe (1988) also focuses on a case of human suffering, involving a five year old girl in Flint, Michigan (E2):

The girl's mother was living with her boyfriend, another man who was unemployed, her two children, and her 9-month old infant fathered by the boyfriend. On New Year's Eve all three adults were drinking at a bar near the woman's home. The boyfriend had been taking drugs and drinking heavily. He was asked to leave the bar at 8:00 p.m. After several reappearances he finally stayed away for good at about 9:30 p.m. The woman and the unemployed man remained at the bar until 2:00 a.m. at which time the woman went home and the man to a party at a neighbour's home. Perhaps out of jealousy, the boyfriend attacked the woman when she walked into the house. Her brother was there and broke up the fight by hitting the boyfriend who was passed out and slumped over a 
table when the brother left. Later the boyfriend attacked the woman again, and this time she knocked him unconscious. After checking the children, she went to bed. Later, the woman's 5-year old girl went downstairs to go to the bathroom. The unemployed man returned from the party at 3:45 a.m. and found the 5-year old dead. She had been raped, severely beaten over most of her body and strangled to death by the boyfriend. (Russell (1989:123), drawing on a report from the Detroit Free Press, January 3, 1986)

E2 is a clear case of moral evil-i.e., a case in which human agents bear responsibility for the resulting suffering. Since there have been anatomically modern humans on earth for about 200,000 years - not to mention the 2, 500, 000 years that have elapsed since our genus homo sapiens first appeared - we can also be sure that there has been a very large amount of suffering of this kind.

\section{Rowe's Arguments}

Over his career, Rowe has advanced various different arguments from intense suffering against the existence of an omnipotent, omniscient, perfectly good being. While there are obvious affinities between these arguments, there are also some significant points of difference as well.

Rowe (1979) discusses the following argument:

1. There exist instances of intense suffering which an omnipotent, omniscient being could have prevented without thereby losing some greater good or permitting some evil equally bad or worse.

2. An omniscient, wholly good being would prevent the occurrence of any intense suffering it could, unless it could not do so without thereby losing some greater good or permitting some evil equally bad or worse.

3. (Therefore) There does not exist an omnipotent, omniscient, perfectly good being.

In justification of the first premise of this argument, there are two significant claims that Rowe makes. First, in connection with the case of the fawn injured in the forest fire, Rowe says:

It must be acknowledged that the case of the fawn's apparently pointless suffering does not prove that (1) is true. ... Perhaps, for all we know, there is some familiar good outweighing the fawn's suffering to which that suffering is connected in a way we do not see. Furthermore, there may well be unfamiliar goods, goods we haven't dreamed of, to which the fawn's suffering is inextricably linked. (337)

But, second, he goes on to add:

In the light of our experience and knowledge of the variety and scale of human and animal suffering in our world, the idea that none of this suffering could have been 
prevented by an omnipotent being without thereby losing a greater good or permitting an evil at least as bad seems an extraordinarily absurd idea, quite beyond our belief. (338)

These points together suggest an implicit argument for the first premise of the central argument of Rowe (1979), along the following lines:

1. There exist instances of intense suffering-E1, E2 - with respect to which, despite long and concerted searching, we have been unable to identify either greater goods that would have been lost had an omnipotent, omniscient being prevented them, or evils equally bad or worse that would have been permitted had an omnipotent, omniscient being prevented them.

2. We have examined many more instances of intense suffering of these kinds, with a view to determining whether an omnipotent, omniscient being could have prevented them without thereby losing some greater good or permitting some evil equally bad or worse, and, in these other cases, too, we have been unable to identify either greater goods that would have been lost had an omnipotent, omniscient being prevented these instances of intense suffering, or evils equally bad or worse that would have been permitted had an omnipotent, omniscient being prevented these instances of intense suffering.

3. We have excellent reason to suppose that the instances of intense suffering of these kinds that we have examined are representative of vastly more numerous instances of intense suffering of these kinds that we have not examined in this way.

4. (Therefore) [Probably] There exist instances of intense suffering which an omnipotent, omniscient being could have prevented without thereby losing some greater good or permitting some evil equally bad or worse.

Rowe (1988) discusses the following argument:

1. No good we know of justifies an omnipotent, omniscient, perfectly good being in permitting particular cases of horrendous suffering (E1 and E2).

2. (Therefore) [Probably] No good at all justifies an omnipotent, omniscient, perfectly good being in permitting particular cases of horrendous suffering (E1 and E2).

3. (Therefore) [Probably] There is no omnipotent, omniscient, perfectly good being.

It is worth noting that this argument makes explicit the previously implicit argument for the existence of evils for which we are unable to identify justifying goods, but that it focuses exclusively on the particular cases (E1 and E2). This seems to me to be a significant difference between the argument of Rowe (1979) and the argument of Rowe (1988).

Rowe (1996) discusses the following argument: 
1. The probability that God exists, conditional on the claim that no good we know of justifies an omnipotent, omniscient, perfectly good being in permitting particular cases of horrendous suffering (E1 and E2), is less than the prior probability that God exists.

2. The prior probability that God exists is 0.5

3. (Therefore) The claim that no good we know of justifies an omnipotent, omniscient, perfectly good being in permitting particular cases of horrendous suffering (E1 and E2) lowers the probability that God exists to something less than 0.5

The first premise of this argument is an instance of a theorem of the probability calculus. Consequently, there is no serious question but that the first premise of this argument is true; and there is also no serious question but that this argument is valid.

\section{Initial Comments on Rowe's Arguments}

As many commentators have observed, there are serious difficulties that confront the argument of Rowe (1996). In particular, almost no one is happy with the second premise: contrary to Rowe's explicit avowal, a prior probability of 0.5 is not a good representation for prior lack of opinion on a matter. (Rather, a prior probability of 0.5 would indicate a prior opinion that there is equal evidential support for both sides of the matter in question.) Moreover, as Otte (2002) suggests, Rowe's argument is an argument from partitioned evidence (though it is not, as Plantinga (1998) complains, an argument from degenerate evidence). Given these difficulties, I think that we do better to focus on the earlier arguments of Rowe (1988) and — in particular-Rowe (1979).

While some have objected to the second premise in the argument of Rowe (1979) - see, for example, Hasker (1992) and van Inwagen (1998)(1991)(2000) — most critical attention has focused on the first premise, and, in particular, on Rowe's attempts to justify the first premise.

Broadly speaking, there are two kinds of responses that have attracted some support. On the one hand, theodicists - e.g. Hick (1966), Hasker (1988), Swinburne (1998), Adams (1999), Stump (2010) - have argued that we are able to identify the greater goods that justify the intense suffering to be found in our universe: freedom, natural law, moral responsibility, moral development, eternal divine felicity, and the like. On the other hand, sceptical theistse.g. Alston (1991)(1996), Bergmann (2001)(2009), Howard-Snyder (1996b)(2009), van Inwagen (1988)(1991)(2000), Wykstra (1984)(1996) - have argued that we should not expect to be able to discern the reasons why an omnipotent, omniscient and perfectly good god permits the range of intense suffering that occurs in our universe: our inability to identify possible reasons is simply no evidence that there are no such reasons.

It is important to be clear about the magnitude of the task faced by theodicists. Consider, again, the case E2. If there is to be a justification for the suffering of the five year old girl, that justification surely must be in terms of goods for her. Moreover, it cannot be that the goods accrued to her prior to her rape, beating and death: the justification for permitting her 
rape, beating and death must be goods that flow to her as a consequence of her being raped, beaten and murdered. For myself, I find it obscene and unspeakable to suppose that nominated great goods flow to her while she is being raped, beaten and murdered. And I find it no less obscene and unspeakable to suppose that her rape, beating and murder were necessary for her to acquire nominated greater goods after she was dead - e.g. eternal divine felicity.

I should acknowledge that it is controversial to claim that justifications for horrendous evils need to be 'patient-centred'. While some theists - e.g. Adams (1999) and Stump (2010) clearly accept that any justification for the suffering of the five year old girl must be in terms of goods for her, other theists - e.g. Alston (1991), Jordan (2004), Mawson (2005) and Swinburne (1998) - (may) deny that this is so. I think that Dostoyevsky (2004) asks exactly the right question: 'Imagine that you are creating a fabric of human destiny with the object of making men happy in the end, giving them peace and rest at last, but that it is essential and inevitable to torture to death only one tiny creature - that baby beating its breast with its fist, for instance - and to found that edifice on its unavenged tears, would you consent to be the architect on those conditions? Tell me, and tell the truth.'

\section{Framework and Assessment}

Before we turn to a more careful consideration of some main issues that arise, I need to make some preliminary observations about arguments, and about the bearing of evidence on theory choice.

In my view, when we come to assess arguments, we need to think about the intended targets of those arguments, and about what the intended targets of those arguments might reasonably believe. When we come to assess the success of an argument, we have to try to see the argument from the standpoint of the intended targets: if we believed what they believe, should we find the argument persuasive?

Given this view about the assessment of arguments, it is doubtless unsurprising that I hold that all extant arguments for and against the existence of God are unsuccessful. In particular, given my view about the assessment of arguments, it is doubtless unsurprising that I hold that Rowe's evidential arguments are unsuccessful. I see no reason why theists are required to accept the first premise of Rowe's argument; I see no reason why we shouldn't say that this is just another of the many claims about which reasonable people can reasonably disagree. True, as I have already indicated, I am inclined to disbelieve the claims made by theodicists and sceptical theists; but it hardly follows that I am required to suppose that theodicists and sceptical theists are irrational — or otherwise cognitively deficient — in denying the first premise of Rowe's argument. And, if I allow that, if I believed what they believe I ought not to be persuaded by Rowe's argument, then it surely follows that I am obliged to conclude that Rowe's argument is unsuccessful.

But, of course, that's not the end of the story. For it is one question whether Rowe's arguments are successful; it is quite another question whether the kinds and amounts of 
suffering to be found in our universe are evidence that our universe was not created by an omnipotent, omniscient and perfectly good god. And that brings us to questions about the assessment of evidence.

I think that we should proceed by imagining a debate between proponents of two different worldviews. One of these worldviews is Theism, which says, among other things, that our universe was created by an omnipotent, omniscient and perfectly good god. The other worldview is Naturalism, which says, among other things, that there are none but natural causes involving none but natural entities. Of course, Naturalism entails Atheism: in particular, Naturalism entails that our universe was not created by an omnipotent, omniscient and perfectly good god, and that there is no omnipotent, omniscient and perfectly good god.

We should focus, in particular, on the theoretical virtues of the worldviews in question. Is either internally inconsistent? Does one have fewer theoretical commitments than the other? Does one have explanatory virtues that are lacked by the other? Does one comport better than the other with independently established theories?

Suppose that we agree — at least for the sake of argument — that both theories are internally consistent. It then seems natural to think that, before we come to consider relevant evidence, Naturalism has an advantage in terms of theoretical commitments. For, while Naturalists are committed only to natural causes involving natural entities, Theists are committed, in addition, to supernatural causes involving supernatural entities. Hence, it also seems natural to think that, if Theism is to be overall more theoretically virtuous than Naturalism, this will have to be because there are local cases in which Theism has an explanatory advantage over Naturalism - and, indeed, that there are sufficiently many, or sufficiently weighty, cases in which Theism has an explanatory advantage over Naturalism to tip the scales in favour of Theism.

How do things stand when it comes to the distribution of intense suffering in our universe? Is this a case in which Theism has an explanatory advantage over Naturalism, or a case in which Naturalism has an explanatory advantage over Theism, or a case in which neither view has an explanatory advantage over the other? On the one hand, there seems to be nothing particularly surprising about the distribution of intense suffering in our universe given the tenets of Naturalism: there is no apparent need to introduce further postulates, or principles, in order to square Naturalism with the distribution of intense suffering in our universe. On the other hand, it seems that there is something at least prima facie surprising about the distribution of intense suffering in our universe given the tenets of Theism: there is, at the very least, an apparently widely felt need to introduce new postulates, or principles, in order to square Theism with the distribution of intense suffering in our universe.

However, if squaring Theism with the distribution of intense suffering in our universe is taken to require the postulation of an afterlife in which there is compensation for that intense suffering, or the postulation of fallen angels who inflict that intense suffering upon us, or the postulation of goods beyond our ken that provide justification for permission of the distribution of intense suffering in our universe by an omnipotent, omniscient, and perfectly 
good god, or the like, then, the distribution of intense suffering in our universe does turn out to favour Naturalism over Theism, since this increase in the theoretical commitments of Theism merely adds to the initial advantage that Naturalism has over Theism on account of theoretical commitments.

Of course, to say that Naturalism has this local advantage over Theism when it comes to the distribution of intense suffering in our universe is not to say that Naturalism trumps Theism (let alone that Naturalism trumps Theism simply because of the distribution of intense suffering in our universe). After all, we have said nothing yet about whether there is independent justification for the postulates in question. It might be that there are other data that are better explained by Theism than by Naturalism in virtue of Theism's postulation of an afterlife, or fallen angels, or goods beyond our ken that provide justification for permission of the distribution of intense suffering by an omnipotent, omniscient, and perfectly good god, or the like. Or it might be that there are other well-established theories that comport better with Theism than with Naturalism in virtue of Theism's postulation of an afterlife, or fallen angels, or goods beyond our ken that provide justification for permission of that distribution of intense suffering by an omnipotent, omniscient, and perfectly good god, or the like. Or it might just be that, even though there is net loss of theoretical virtue involved in the postulation of an afterlife, or fallen angels, or goods beyond our ken that provide justification for permission of the distribution of intense suffering by an omnipotent, omniscient, and perfectly good god, or the like, this net loss in theoretical virtue is offset by net gains elsewhere (in connection with considerations about the origins of causal reality, or the finetuning of causal reality, or the presence of consciousness and reason in causal reality, or the insignificance of human beings on any cosmic scale, or the apparent objectivity of various normative domains, or the range and distribution of religious belief, or the nature and existence of diverse canonical religious texts, or the full range of attestations to the occurrence of 'anomalous' phenomena, or the quantities and distribution of various kinds of great goods in our universe, and so forth). However, unless there is independent reason for Naturalism to posit an afterlife, or fallen angels, or goods beyond our ken that provide justification for permission of the distribution of intense suffering by an omnipotent, omniscient, and perfectly good god, or the like, it seems undeniable that Naturalism does have a local advantage over Theism when it comes to the distribution of intense suffering in our universe.

Perhaps it might be objected that, if Naturalism has a local advantage over Theism when it comes to the distribution of intense suffering in our universe, then it should be possible to encode that local superiority in a successful argument. And perhaps it might be added that, in fact, Rowe's argument does exactly that. However, I do not think that this is so. True enough, Rowe consistently frames his arguments in a context in which other considerations are meant to be ignored: he never suggests that considerations about intense suffering are decisive evidence against the existence of an omnipotent, omniscient, and perfectly good god. Nonetheless, Rowe's arguments are not framed as comparisons of theism with alternative worldviews; rather, they aim for a non-comparative conclusion about the absolute epistemic 
or doxastic value of theism relative to the particular evidence that is the distribution of intense suffering in our universe. But I do not think that any argument of this kind can succeed. As I have already noted, I think that Rowe's (1979) formulation of his first premise invites the response that, while Naturalists can reasonably suppose that the first premise is true, Theists can reasonably suppose that the first premise is false. Certainly, for all that is given in the argument, there is no reason why Theists cannot reasonably deny the first premise of Rowe's (1979) argument.)

Perhaps some will think that the claim to scepticism that I have just made sounds similar to claims made by Paul Draper (1989) (2004). However, the framework for assessment of theories (or worldviews) that I have sketched is rather different from the framework that Draper adopts. In particular, I have not suggested that we should proceed by trying to compare the probabilities that theories have relative to some evidence: I do not believe that we currently have any effective method, for comparing the probabilities that theories have relative to evidence, that overcomes the difficulties posed by reasonable disagreement about the prior probabilities of theories. In the absence of effective methods for turning judgements about theoretical virtues into probabilistic judgements, it seems to me that the only way forward is to make direct comparisons between theories, on given evidence, in terms of the various theoretical virtues. But if all of that is right, then, (a) Rowe's formulation is defective because it is not couched in terms of comparisons between competing theories; (b) Draper's formulation fails because it does not focus on the right kinds of comparisons between competing theories; and (c) both approaches are defective because they try to produce standard-form arguments in circumstances in which the production of standard-form arguments is simply surplus to requirements.

\section{A Central Issue}

Might there be independent reason for Naturalism to posit goods beyond our ken that would provide justification for permission, by an omnipotent, omniscient, and perfectly good god, of the distribution of intense suffering in our world (if there were an omnipotent, omniscient and perfectly good god)? In particular, might there be independent reason for Naturalism to posit goods beyond our ken that would provide justification for permission, by an omnipotent, omniscient, and perfectly good god, of the rape, torture and murder of five year old girls (if there were an omnipotent, omniscient and perfectly good god)?

That seems implausible. After all, Naturalists have no more reason to suppose that there are goods beyond our ken that would provide justification for permission, by an omnipotent, omniscient, and perfectly good god, of the rape, torture and murder of five year old girls (if there were an omnipotent, omniscient and perfectly good god) than they have to suppose that there are evils beyond our ken that would provide justification for prevention, by an omnipotent, omniscient and perfectly good god, of attendance at Christian churches by five year old girls (if there were an omnipotent, omniscient and perfectly good god). Which is just to say that Naturalists have no reason at all to suppose that there are goods beyond our ken that would provide justification for permission, by an omnipotent, omniscient, and perfectly 
good god, of the rape, torture and murder of five year old girls (if there were an omnipotent, omniscient and perfectly good god). But, absent good reason to postulate such goods, on straightforward grounds of theoretical virtue, Naturalists should not do so.

However, even if it is accepted that Naturalism ought have no truck with goods beyond our ken that would provide justification for permission, by an omnipotent, omniscient, and perfectly good god, of the rape, torture and murder of five year old girls (if there were an omnipotent, omniscient and perfectly good god), it might nonetheless be supposed that those who are inclined to embrace Naturalism ought to exercise caution when it comes to the question of goods beyond our ken that would provide justification for permission, by an omnipotent, omniscient, and perfectly good god, of the rape, torture and murder of five year old girls (if there were an omnipotent, omniscient and perfectly good god). After all, it is one thing to embrace Naturalism; it is quite another to be absolutely certain that Naturalism is true.

I understand Sceptical Theism to be a position that endorses the view that even those who embrace Naturalism ought to be unsure whether there are goods beyond our ken that would provide justification for permission, by an omnipotent, omniscient, and perfectly good god, of the rape, torture and murder of five year old girls (if there were an omnipotent, omniscient and perfectly good god). Thus understood, Sceptical Theism might be explained in terms of commitment to theses such as the following (see, e.g., Howard-Snyder (2009:18), and, for comparison, Bergmann (2001) (2009); and for somewhat different ways of understanding Sceptical Theism, see, e.g., Wykstra (1984) (1996), and Alston (1991) (1996)):

1. We should be in doubt about whether the goods we can know of constitute a representative sample of all the goods there are with respect to being apt for justifying permission, by an omnipotent, omniscient, and perfectly good god, of the rape, torture and murder of five year old girls (if there were an omnipotent, omniscient and perfectly good god).

2. We should be in doubt about whether each good we can know of is such that the necessary conditions of its realisation we can know of are all there are with respect to being apt for justifying permission, by an omnipotent, omniscient, and perfectly good god, of the rape, torture and murder of five year old girls (if there were an omnipotent, omniscient and perfectly good god).

Why might it be thought that even those who embrace Naturalism ought to be prepared to endorse these theses? At least the following considerations have been advanced in the literature:

Progress: Given the patchy evidence that we have concerning the occasional discovery of new intrinsic goods over the past few millennia, it would not be surprising if there remain goods that we have not yet discovered. (Howard-Snyder (1999:111).) 
Complexity: Quite generally, increasing complexity correlates with increased difficulty in understanding. Given that intense suffering is so awful, it is hardly surprising that outweighing goods would have to be so complex that they would evade our understanding. (Howard-Snyder (1999:111).)

Fallibility: If we are to suppose that the goods we know of constitute a representative sample of all the goods there are with respect to being apt for justifying permission, by an omnipotent, omniscient, and perfectly good god, of the rape, torture and murder of five year old girls (if there were an omnipotent, omniscient and perfectly good god), then we need to suppose that we possess the concepts needed to comprehend and understand every member of the total population of goods apt for justifying permission, by an omnipotent, omniscient, and perfectly good god, of the rape, torture and murder of five year old girls (if there were an omnipotent, omniscient and perfectly good god). But surely it would be an extraordinary stroke of good epistemic luck if our evolutionary history to this point left us with every concept needed to comprehend and understand every member of the total population of goods apt for justifying permission, by an omnipotent, omniscient, and perfectly good god, of the rape, torture and murder of five year old girls (if there were an omnipotent, omniscient and perfectly good god). (Howard-Snyder (2009: 26f.))

Analogies: To reject the theses set out above is to 'take insights attainable by finite, fallible human beings as an adequate indication of what is available in the way of reasons to an omniscient, omnipotent being' (Alston (1996:316).) Rejection of the theses 'involves trying to determine whether there is a so-and-so in a territory the extent and composition of which is largely unknown to us' (Alston (1996:319).) We stand to God in something like the way that young human children stand to their human parents, only more so: but of course we all understand that young human children often do not have what it takes to understand some of the goods of human existence.

These considerations seem to me to be far from compelling.

It seems reasonable to grant that there is evidence of occasional discoveries concerning intrinsic goods over the past few millennia; and it also seems reasonable to grant that this is some reason to suppose that we shall make further discoveries concerning intrinsic goods in the coming millennia (so long as humanity survives long enough to make such discoveries). But, in the nature of the case, intrinsic goods that we shall discover are not goods beyond our ken (i.e. goods that are beyond our powers of comprehension): there is no reason to suppose that our having occasionally made discoveries concerning intrinsic goods is evidence that there are considerations concerning intrinsic goods that we lack the capacity to recognise. Moreover - and perhaps more importantly - there is nothing in the new intrinsic goods that have been discovered in the past few millennia that suggests reasons to suppose that there are goods apt for justifying permission, by an omnipotent, omniscient, and perfectly good god, of the rape, torture and murder of five year old girls (if there were an omnipotent, omniscient and perfectly good god). Yes, we've come to recognise that slavery is intrinsically wrong, and that homosexuality is not intrinsically wrong, and so forth: but where, in any of this, is 
there reason to suppose that there are goods - let alone goods beyond our ken - apt for justifying permission, by an omnipotent, omniscient, and perfectly good god, of the rape, torture and murder of five year old girls (if there were an omnipotent, omniscient and perfectly good god)?

It seems reasonable to grant that there is some correlation between increasing complexity and increasing difficulty in understanding. But it is hard to discern any good reason for thinking that, because intense suffering is so awful, outweighing goods would need to be very complicated (and, indeed, so complicated that they would evade our understanding). After all, the simple fact is that we have no trouble at all recognising intense suffering and identifying that it is awful. But, given that intense suffering need not be especially complicated-and certainly need not be so complicated as to evade our understanding - why on earth should we suppose that outweighing goodness must be so fiendishly complicated as to evade our understanding? Why shouldn't we rather suppose that outweighing goodness would simply be correspondingly intense goodness? (Cf. Tooley (1991) for related thoughts.)

I think that nothing could justify rape, torture and murder of five year old girls; and I think that nothing could justify inaction in the face of rape, torture and murder of five year old girls other than inability (on grounds of lack of power, or knowledge, or the like). Rather than concede that it would be an extraordinary stroke of good epistemic luck if our evolutionary history to this point left us with every concept needed to comprehend and understand every member of the total population of goods apt for justifying permission, by an omnipotent, omniscient, and perfectly good god, of the rape, torture and murder of five year old girls (if there were an omnipotent, omniscient and perfectly good god), I say that the emptiness of the population of goods apt for justifying permission, by an omnipotent, omniscient, and perfectly good god, of the rape, torture and murder of five year old girls (if there were an omnipotent, omniscient and perfectly good god) explains why epistemic luck is simply beside the point. Our evolutionary history to this point has left us with all of the concepts needed to understand all of the members of the total population of goods apt for justifying permission, by an omnipotent, omniscient, and perfectly good god, of the rape, torture and murder of five year old girls (if there were an omnipotent, omniscient and perfectly good god), because that population has no members, and so no concepts at all are required for the understanding in question. Putting the point in a way that doesn't beg any questions: whether it would be an extraordinary stroke of good epistemic luck if our evolutionary history to this point left us with every concept needed to comprehend and understand every member of the total population of goods apt for justifying permission, by an omnipotent, omniscient, and perfectly good god, of the rape, torture and murder of five year old girls (if there were an omnipotent, omniscient and perfectly good god) depends upon whether there are any goods apt for justifying permission, by an omnipotent, omniscient, and perfectly good god, of the rape, torture and murder of five year old girls (if there were an omnipotent, omniscient and perfectly good god). (Again, cf. Tooley (1991) and Rowe (1996) for related arguments.)

It seems to me to be quite clear that rejection of the Sceptical Theist theses does not require taking insights attainable by finite, fallible human beings as an adequate indication of what is 
available in the way of reasons to an omniscient, omnipotent being. True enough, one of the theories that we are deciding between is committed to the existence of an omnipotent, omniscient, perfectly good god. And, on that theory, it will be supposed that there are goods apt for justifying permission, by an omnipotent, omniscient, and perfectly good god, of the rape, torture and murder of five year old girls. But the decision between the theories is a matter for finite, fallible, human beings: we can only weigh the considerations that are available to us. On the one hand, Theism is committed to an omnipotent, omniscient and perfectly good god who acts for reasons that may be inaccessible to us; on the other hand, Naturalism is committed neither to an omnipotent, omniscient and perfectly good god, nor to actions of that god on the basis of reasons that may be inaccessible to us. If Naturalists are right, then we do better to reject both god and the (possibly) inaccessible reasons upon which god acts. (Considerations about 'a territory the extent and composition of which is largely unknown to us' and the parent/child analogy were, I think, adequately addressed in the previous response to the 'Fallibility' objection.)

Aside from the weakness of the arguments that have been offered in defence of the claim that even those who embrace Naturalism ought to be prepared to endorse these theses, there are also fairly strong considerations that militate against that claim. As I noted earlier, if there were to be a justification for the permission, by an omnipotent, omniscient, and perfectly good god, of the rape, torture and murder of five year old girls (if there were an omnipotent, omniscient and perfectly good god), that justification would surely have to be in terms of goods for the five year old girls in question. But it cannot be that the goods are accrued by the girls prior to their rape, torture and murder: the justification for permitting the rape, beating and murder must be in terms of goods the flow to the girls as a result of their being raped, beaten and murdered. But it is obscene and unspeakable to suppose that great goods flow to the girls while they are being raped, beaten and murdered; and it is impossible for great goods to flow to the girls after they cease to exist (as a result of having been raped, beaten and then murdered). But, if there is no point at which the girls can accrue goods as a result of their having been raped, beaten and murdered, then there is no room for doubt about whether the goods we can know of constitute a representative sample of all the goods there are with respect to being apt for justifying permission, by an omnipotent, omniscient, and perfectly good god, of the rape, torture and murder of five year old girls (if there were an omnipotent, omniscient and perfectly good god), or about whether each good we can know of is such that the necessary conditions of its realisation we can know of are all there are with respect to being apt for justifying permission, by an omnipotent, omniscient, and perfectly good god, of the rape, torture and murder of five year old girls (if there were an omnipotent, omniscient and perfectly good god).

I conclude that not only is there no reason for Naturalism to posit goods beyond our ken that would provide justification for permission, by an omnipotent, omniscient, and perfectly good god, of the distribution of intense suffering in our world (if there were an omnipotent, omniscient and perfectly good god), there is also no reason for Naturalists to accept the kinds of theses to which Sceptical Theists are typically committed: Naturalists should not be in 
doubt about whether the goods we can know of constitute a representative sample of all the goods there are with respect to being apt for justifying permission, by an omnipotent, omniscient, and perfectly good god, of the rape, torture and murder of five year old girls (if there were an omnipotent, omniscient and perfectly good god); and Naturalists should not be in doubt about whether each good we can know of is such that the necessary conditions of its realisation we can know of are all there are with respect to being apt for justifying permission, by an omnipotent, omniscient, and perfectly good god, of the rape, torture and murder of five year old girls (if there were an omnipotent, omniscient and perfectly good god).

\section{A Further Consideration}

Naturalists might take the following argument to encode another reason for rejecting the kinds of theses to which Sceptical Theists are typically committed:

1. If we should be unsure whether there are great goods that flow to five year old girls who are raped, tortured and murdered, as a result of their being raped, tortured and murdered, then we should be unsure whether we ought to intervene to prevent the rape, torture, and murder of five year old girls even when we are in a position to do so at no cost to ourselves.

2. We should not be unsure whether we ought to intervene to prevent the rape, torture, and murder of five year old girls even when we are in a position to do so at no cost to ourselves.

3. (Therefore) We should not be unsure whether there are great goods that flow to five year old girls who are raped, tortured and murdered, as a result of their being raped, tortured and murdered.

Against this argument, Howard-Snyder (2009) objects that there is no theory of the rightmaking and wrong-making properties of actions that can vindicate both of its premises. I disagree.

Think of decision situations in the following terms: there are a bunch of actions $A_{i}$ between which we must decide, a bunch of possible states of the world $S_{j}$ (to which we ascribe probabilities $\mathrm{p}_{\mathrm{j}}$ ), and a bunch of values $\mathrm{V}_{\mathrm{ij}}$ (representing the values that we attach to our performing the actions $A_{i}$ given the states $S_{j}$ ). We suppose that our decision rule tells us to choose the action $A_{i}$ that maximises the value of $\sum_{j} p_{j} V_{i j}$. Note that we make no assumptions about the nature of the values: they can be deontic, or consequentialist, or virtue-theoretic, or whatever else floats your boat.

In the case in which we are interested, we must choose between intervening to prevent the rape, torture and murder of a five year old girl (at no cost to ourselves), and not intervening to prevent the rape, torture and murder of a five year old girl (at no cost to ourselves). We suppose that we assign very large disvalue to all of the act/state pairs in which we do not intervene to prevent the rape, torture and murder of the girl (at no cost to ourselves); and that 
we do not assign very large disvalue to any of the act/state pairs in which we do intervene to prevent the rape, torture and murder of the girl (at no cost to ourselves).

On the one hand, given that there are no other relevant considerations, it is clear that our calculation will tell us to intervene, and that there is no doubt that our calculation will tell us to intervene. It is not merely the case that we ought to intervene to prevent the rape, torture, and murder of the five year old girl; we should not be unsure whether we ought to intervene to prevent the rape, torture, and murder of the five year old girl. So the second premise of the argument is clearly vindicated.

On the other hand, if we are unsure whether outweighing goods will accrue to the girl as a result of her being raped, tortured and murdered, then we cannot now reach the same conclusion as before: we must now be unsure whether we should assign very large disvalue to all of the act/state pairs in which we do not intervene to prevent the rape, torture and murder of the girl (at no cost to ourselves). Which is just to say that the first premise of the argument is clearly vindicated. (Consider this: 'It is hard to say whether or not created persons must be permitted to undergo horrific suffering in order to enter into the deepest union with God. ... For all we can tell, there are aspects of God's nature that we do not know of in virtue of which a created person can enter into the deepest union with God only if she is permitted to undergo horrific suffering' (Howard-Snyder (2009:27).). Well, if I'm not sure whether this five year old girl's deepest union with God depends upon her being raped, tortured and murdered here and now, how can I be sure that I ought to intervene to prevent her rape, torture and murder here and now? Heaven forfend that I should stand between her and deepest union with God!)

Why does Howard-Snyder think that there is something wrong with this line of thought? I think because he supposes that the weight of 'unforeseeable values' of our actions prevents us from ever performing the kinds of calculations that I have suggested are involved whenever we make decisions under uncertainty.

I think that 'unforeseeable values' are handled in decision theory in something like the following way: the values $V_{i j}$ are really of the form $R_{i j} \pm C$, where $\pm C$ is a constant that takes the same value for each of the $\mathrm{R}_{\mathrm{ij}}$. The point is that the 'unforseeable' value that attaches to each act/state pair has to be the same: 'forseeable' value is all built into the $\mathrm{R}_{\mathrm{ij}}$. But, of course, once this point is noted, we see that we can simply write $\mathrm{Rij} \pm \mathrm{C}$ as $\mathrm{V}_{\mathrm{ij}}$ : for the $\pm \mathrm{C}$ will simply have no effect on the final calculation, and so can be 'renormalised' away.

Against this kind of suggestion, Howard-Snyder says: 'Given that intervention and nonintervention have massive and inscrutable causal ramifications, and given that the unforeseeable consequences swamp the foreseeable ones, we have just as much reason to believe that the total consequences of non-intervention outweigh the total consequences of intervention as we have to believe that the total consequences of intervention outweigh the total consequences of non-intervention. Thus, we should be in doubt about whether we should intervene.' (38). But — as we saw above - it is simply not true that the unforeseeable consequences 'swamp' the foreseeable consequences. Of course, something like the 
I conclude that the argument in question does encode further reason for Naturalists to reject the kinds of theses to which Sceptical Theists are typically committed. However, I hasten to add, I do not suppose that this argument encodes reasons for Theists to reject the kinds of theses to which Sceptical Theists are typically committed. As Howard-Snyder (2009: 43f) observes, Theists may well suppose, for example, that God has instructed humankind to prevent suffering in general, and that God permits a lot of it precisely because he intends for us to try to prevent it. (So, somehow, I would not stand between the five year old girl and her deepest union with God were I to intervene to prevent her rape, torture and murder.)

Nonetheless, I must observe that, in the context of the choice between Naturalism and Theism that I have taken to be the proper framework for evaluation of the evidential import of intense suffering, the claim that God has instructed humankind to prevent suffering in general, etc. further increases the advantage that Naturalism has over Theism in respect of theoretical commitments. Unless there is other evidence that supports the claim that God has instructed humankind to prevent suffering in general, etc., it does turn out to be the case that considerations about intense suffering favour Naturalism over Theism; and, more generally, unless Theism otherwise possesses theoretical virtues that outweigh the theoretical losses involved in accommodating data concerning intense suffering, it does turn out to be the case that considerations about intense suffering decisively favour Naturalism over Theism.

Thanks to Dan Howard-Snyder and Justin McBrayer for the invitation to contribute to this volume, and for their enthusiastic and sage editorial advice and assistance. Thanks, too, to Klaas Kraay and an anonymous referee for many helpful suggestions that have led to improvements of this chapter. Of course, none of the above should be blamed for any of the numerous faults that remain.

\section{References and Further Reading}

Adams, M. (1999) Horrendous Evils and the Goodness of God Melbourne: Melbourne University Press

Almeida, M. and Oppy, G. (2003) 'Sceptical Theism and Evidential Arguments from Evil' Australasian Journal of Philosophy 81, 496-516

Alston, W. (1991) 'The Inductive Argument from Evil and the Human Cognitive Condition' Philosophical Perspectives 5, 29-67

Alston, W. (1996) 'Some (Temporarily) Final Thoughts on Evidential Arguments from Evil' in D. Howard-Snyder (ed.) (1996a), 97-125

Beaudoin, J. (2005) 'Skepticism and the Skeptical Theist' Faith and Philosophy 22, 1, 42-56 
Beilby, J. (1995) 'William Rowe on the Evidential Value of Appearances' Faith and Philosophy 12, 251-9

Beilby, J. (1996) 'Does the Empirical Problem of Evil Prove that Theism is Improbable?' Religious Studies 32, 315-23

Bergmann, M. (2001) 'Skeptical Theism and Rowe's New Evidential Argument from Evil' Noûs 35, 278-96

Bergmann, M. (2009) 'Skeptical Theism and the Problem of Evil' in T. Flint and M. Rea (eds.) The Oxford Handbook of Philosophical Theology New York: Oxford University Press

Bergmann, M. and Howard-Snyder, D. (2001) 'Grounds for Belief Aside, Does Evil Make Atheism More Reasonable than Theism?’ in W. Rowe (ed.) (2001a), 140-55

Bergmann, M. and Rea, M. (2005) 'In Defense of Skeptical Theism: A Reply to Almeida and Oppy" Australasian Journal of Philosophy 83, 241-51

Chrzan, K. (1987) 'Debunking CORNEA' International Journal for Philosophy of Religion $21,171-7$

Chrzan, K. (1988) 'When is a Gratuitous Evil Really Gratuitous?' International Journal for Philosophy of Religion 24, 87-91

Dostoyevsky, F. (2004) The Brothers Karamazov, translated by C. Garnett New York: Barnes \& Noble

Dougherty, T. (2008) 'Epistemological Considerations Concerning Skeptical Theism' Faith and Philosophy 25, 2, 172-6

Dougherty, T. (2011a) 'Further Epistemological Considerations Concerning Skeptical Theism' Faith and Philosophy 28, 3, 332-40

Dougherty, T. (2011b) 'Recent Work on the Problem of Evil' Analysis 71, 3, 560-73

Draper, P. (1989) Pain and Pleasure: An Evidential Problem for Theists Noûs 23, 331-50

Draper, P. (1996) 'The Sceptical Theist' in D. Howard-Snyder (ed.) (1996a)

Draper, P. (2004) 'Cosmic Fine-Tuning and Terrestrial Suffering: Parallel Problems for Naturalism and Theism' American Philosophical Quarterly 41, 311-21

Gelinas, L. (2009) 'The Problem of Natural Evil' Philosophy Compass 4, 3, 533-59

Hasker, W. (1988) 'Suffering, Soul-Making, and Salvation' International Philosophical Quarterly 28, 3-19

Hasker, W. (1992) 'The Necessity of Gratuitous Evil' Faith and Philosophy 9, 23-44 
Hick, J. (1966) Evil and the God of Love London: Macmillan

Howard-Snyder, D. (1992) 'Seeing through CORNEA' International Journal for Philosophy of Religion 32, 25-49

Howard-Snyder, D. (ed.) (1996a) The Evidential Argument from Evil Bloomington: Indiana University Press

Howard-Snyder, D. (1996b) 'The Argument from Inscrutable Evil' in D. Howard-Snyder (ed.) (1996a), 286-310

Howard-Snyder, F. and Howard-Snyder, D. (1999) 'Is Theism Compatible with Gratuitous Evil?’ American Philosophical Quarterly 36, 115-29

Howard-Snyder, D. (2009) 'Epistemic Humility, Arguments from Evil, and Moral Skepticism' Oxford Studies in Philosophy of Religion 2, 17-57

Jordan, J. (2001) 'Blocking Rowe's New Evidential Argument from Evil' Religious Studies $37,435-49$

Jordan, J. (2004) 'Divine Love and Human Suffering' International Journal for Philosophy of Religion 56, 169-78

Jordan, J. (2006) 'Does Skeptical Theism Imply Moral Skepticism?' Philosophy and Phenomenological Research 72, 403-17

Langtry, B. (1996) 'Eyeballing Evil: Some Epistemic Principles’ Philosophical Papers 25, 127-37

Laraudogoitia, J. (2000) 'CORNEA against Theism' International Journal for Philosophy of Religion 48, 81-7

Lovering, R. (2009) 'On what God would do' International Journal for Philosophy of Religion 42, 2, 79-96

Maitzen, S. (2007) 'Skeptical Theism and God's Commands' Sophia 35, 235-41

Maitzen, S. (2009) 'Skeptical Theism and Moral Obligation' International Journal for Philosophy of Religion 65, 2, 93-103

Matheson, J. (2011) 'Epistemological Considerations Concerning Skeptical Theism: A Response to Dougherty' Faith and Philosophy 28, 3, 323-21

Mawson, T. (2005) Belief in God Oxford: Oxford University Press (Chapter 12, 'The Problem of Evil', 198-217)

McBrayer, J. (2010) ‘Skeptical Theism’ Philosophy Compass 5, 7, 611-23 
Napier, S. (2002) 'Is Rowe Committed to an Expanded Version of Theism?' Sophia 41, 3140

O’Connor, D. (1990) ‘A Sceptical Defense of Theism' Proceedings of the American Catholic Philosophical Association 64, 221-40

O’Leary-Hawthorne, J. and Howard-Snyder, D. (1994) 'On the A Priori Rejection of Evidential Arguments from Evil' Sophia 33, 33-47

Otte, R. (2000) 'Evidential Arguments from Evil’ International Journal for Philosophy of Religion 48, 1-10

Otte, R. (2002) 'Rowe’s Probabilistic Argument from Evil’ Faith and Philosophy 19, 147-71

Piper, M. (2007) 'Skepticism, Theism and the Problem of Moral Aporia' International Journal for Philosophy of Religion 62, 2, 65-79

Piper, M. (2008) 'Why Theists Cannot Accept Skeptical Theism’ Sophia 47, 2, 129-48

Plantinga, A. (1998) 'Degenerate Evidence and Rowe's New Evidential Argument from Evil' Noûs 32, 531-44

Rowe, W. (1979) 'The Problem of Evil and Some Varieties of Atheism' American Philosophical Quarterly 16, 335-41

Rowe, W. (1986) 'The Empirical Argument from Evil' in R. Audi and W. Wainwright (eds.) Rationality, Religious Belief and Moral Commitment Ithaca: Cornell University Press, 227-47

Rowe, W. (1988) 'Evil and Theodicy’ Philosophical Topics 16, 119-32

Rowe, W. (1991) 'Ruminations about Evil’ Philosophical Perspectives 5, 69-88

Rowe, W. (1996) 'The Evidential Argument from Evil: A Second Look' in D. HowardSnyder (ed.) (1996a), 262-85

Rowe, W. (2001a) ‘Skeptical Theism: A Response to Bergmann’ Noûs 35, 297-303

Rowe, W. (ed.) (2001b) God and the Problem of Evil Malden: Blackwell

Rowe, W. (2001c) 'Grounds for Belief Aside, Does Evil Make Atheism More Reasonable than Theism?' in W. Rowe (ed.) (2001a), 124-37

Rowe, W. (2001d) 'Reply to Howard-Snyder and Bergmann' in W. Rowe (ed.) (2001a), 1558

Russell, B. (1989) ‘The Persistent Problem of Evil' Faith and Philosophy 6, 121-39

Russell, B. (1996) 'Defenceless’ in D. Howard-Snyder (ed.) (1996a), 193-205 
Schellenberg, J. (1993) Divine Hiddenness and Human Reason Ithaca: Cornell University Press

Schellenberg, J. (2000) 'Stalemate and Strategy: Rethinking the Evidential Argument from Evil’ American Philosophical Quarterly 37, 405-19

Schnall, I. (2007) 'Skeptical Theism and Moral Skepticism’ Religious Studies 43, 49-69

Segal, A. (2011) 'Sceptical Theism and Divine Truth’ Religious Studies 47, 1, 85-95

Sennett, J. (1993) 'The Inscrutable Evil Defense Against the Inductive Argument from Evil' Faith and Philosophy 10, 220-9

Stump, E. (2010) Wandering in Darkness: Narrative and the Problem of Suffering Oxford: Oxford University Press

Swinburne, R. (1998) Providence and the Problem of Evil Oxford: Clarendon

Tooley, M. (1991) ‘The Argument from Evil’ Philosophical Perspectives 5, 89-134

Trakakis, N. (2003) 'What No Eye has Seen: The Skeptical Theist Response to Rowe's Evidential Argument from Evil' Philo 6, 263-79

Trakakis, N. (2007) The God Beyond Belief: In Defence of William Rowe's Evidential Argument from Evil New York: Springer

Van Inwagen, P. (1988) 'The Place of Chance in a World Sustained by God' in T. Morris (ed.) Divine and Human Action: Essays in the Metaphysics of Theism Ithaca: Cornell University Press, 211-35

Van Inwagen, P. (1991) 'The Problem of Evil, the Problem of Air, and the Problem of Silence’ Philosophical Perspectives 5, 135-65

Van Inwagen, P. (2000) 'The Argument from Particular Horrendous Evils' Proceedings of the American Catholic Philosophical Association 74, 65-80

Wielenberg, E. (2010) 'Sceptical Theism and Divine Lies’ Religious Studies 46, 4, 509-23

Wilks, I. (2004) 'The Structure of the Contemporary Debate on the Problem of Evil' Religious Studies 40, 3, 307-21

Wilks, I. (2009) 'Skeptical Theism and Empirical Unfalsifiability' Faith and Philosophy 26, $1,64-76$

Wykstra, S. (1984) 'The Humean Obstacle to Evidential Arguments from Suffering: On Avoiding the Evils of "Appearance"' International Journal for Philosophy of Religion $16,73-94$

Wykstra, S. (1996) 'Rowe’s Noseeum Arguments from Evil’ in Howard-Snyder (1996a) 
